\title{
PEMAHAMAN MAHASISWA TEKNIK SIPIL TERHADAP KONSEP NILAI П PADA KELILING DAN LUAS LINGKARAN
}

\author{
Fitri Aida Sari ${ }^{1}$, Dadang Juandi ${ }^{2}$ \\ ${ }^{\text {I}}$ Program Studi Teknik Sipil, Universitas Banten Jaya, Jl. Raya Ciwaru II No.73 Kota Serang, Banten \\ ${ }^{1,2}$ Program Studi Pendidikan Matematika, Universitas Pendidikan Indonesia, Bandun \\ Email: fitriaidasari@unbaja.ac.id \\ Email:dadangjuandi@upi.ac.id
}

\begin{abstract}
ABSTRAK
Lingkaran merupakan salah satu materi yang dapat kita temukan dalam mata pelajaran matematika di berbagai tingkat pendidikan baik sekolah dasar, sekolah menengah bahkan perguruan tinggi. Banyak hal menarik yang dapat kita bahas pada materi lingkaran, salah satunya mengenai penggunaan nilai $\pi$ pada keliling dan luas lingkaran. Penelitian ini bertujuan untuk mengetahui pemahaman mahasiswa teknik sipil terkait nilai $\pi$ yang digunakan untuk menyelesaikan permasalahan pada keliling serta luas lingkaran. Metode penelitian ini menggunakan metode kualitatif deskriptif dimana peneliti menjelaskan hasil yang diperoleh dari angket terbuka dan wawancara yang dilakukan kepada 27 responden yang merupakan mahasiswa teknik sipil tingkat 2. Hasil penelitian ini menunjukkan banyak mahasiswa yang masih mengalami kesulitan dalam menentukan pendekatan nilai $\pi$ yang tepat, bukan hanya itu bahkan sebelum mensubstitusikan nilai $\pi$ ke dalam langkah yang tepat, banyak mahasiswa yang masih mengalami kesulitan dalam memilih cara penyelesaian yang tepat sehingga jika dosen ingin membahas penerapan konsep nilai $\pi$ dalam bidang teknik sipil maka terlebih dahulu harus menjelaskan dari mana nilai itu didapatkan dan menjelaskan kembali materi yang berhubungan dengan nilai $\pi$ tersebut seperti materi lingkaran.
\end{abstract}

Kata kunci: Lingkaran, Nilai $\pi$, Keliling, Luas.

\section{PENDAHULUAN}

Geometri merupakan bagian matematika yang membahas tentang bentuk dan ukuran dari suatu obyek yang memiliki keteraturan tertentu (Clemens, S. R., O’Daffer, P. G., \& Cooney, 1984). Geometri sudah dikenalkan sejak siswa menempuh pendidikan di Sekolah Dasar seperti mengenal bola dan bukan bola, tabung dan bukan tabung, balok dan bukan balok, lingkaran dan bukan lingkaran, segitiga dan bukan segitiga, segiempat dan bukan segiempat, menggambar bangun datar, bangun ruang, menghitung panjang, luas, hingga volume pada batas-batas yang sesuai untuk tingkatan SD. Di tingkat Sekolah Menengah Pertama siswa dikenalkan dengan pembahasan mengenai menghitung luas bangun datar, luas permukaan berbagai bangun ruang serta volumenya. Di tingkat Sekolah Menengah Atas siswa belajar mengenai posisi titik, garis dan bidang pada bangun rung serta menghitung jaraknya. Pada tingkat perguruan tinggi seharusnya materi mengenai bangun ruang sudah dikuasai dengan baik oleh mahasiswa dan tinggal menerapkannya di dalam bidang ilmu yang akan dipilih oleh mahasiswa. Namun, pada kenyatannya mahasiswa belum menguasai konsep ini, bahkan untuk konsep dasarnya seperti konsep nilai $\pi$ yang biasa digunakan dalam menghitung luas dan keliling lingkaran serta volume dan luas permukaan bangun ruang yang memiliki alas berupa lingkaran seperti tabung dan kerucut belum mahasiswa pahami dengan baik. 
$\pi$ merupakan salah satu huruf Yunani yang merupakan huruf ke 16 lihat Gambar 1), pada saat ini kita lebih mengenal $\pi$ sebagai salah satu simbol yang digunakan di dalam matematika. Seperti yang kita ketahui bahwa banyak buku yang secara langsung menyatakan nilai $\pi=3,14$ dikarenakan digit-digit $\pi$ akan menyulitkan perhitungan jika terlalu banyak digunakan. Misalnya untuk menghitung luas lingkaran, atau volume bola dan tabung, akan kesulitan jika memaksakan digit yang 10 triliun itu sebagai nilai $\pi$. Akan berbeda tentunya jika menggunakan 3,14 yang akan sangat memudahkan dalam menyelesaikan permasalahan matematis.

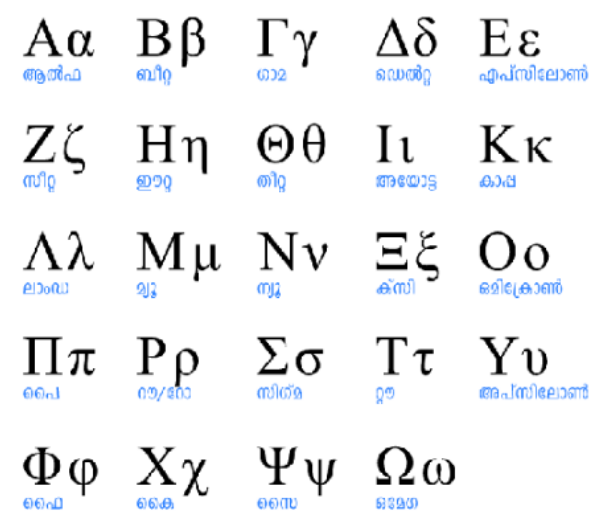

Gambar 1. Daftar Huruf Alfabet Yunani

(Likuang, 2019)

Penentuan angka yang disematkan pada $\pi$ telah menjadi objek penelitian banyak orang dari berabadabad tahun yang lalu. Nilai $\pi$ merupakan salah satu subjek penelitian tertua di dalam pelajaran matematika yang mana Bangsa Babilonia dan Mesir Kuno sudah meneliti ini sejak tahun 2000 SM (Syam, 2017). Pada perkembangannya, banyak orang yang menafsirkan besar nilai $\pi$ diantaranya, pada tahun 1900 - 1600 SM ditemukan sebuah lempeng liat dari Babilonia yang mengasumsikan $\pi$ sebagai $\frac{25}{8}=3 \frac{1}{8}=3,1250$. Pada dokumen mesir kuno (Rhind Papyrus) yang diperkirakan dibuat tahun 1650 SM telah diasumsikan sebuah lingkaran setara dengan diameter yang dibagi sembilan dan memiliki area yang sama dalam sebuah persegi berasumsikan sisi delapan, hal ini memperlihatkan $\pi \frac{d^{2}}{4}=\left(\frac{8 d}{9}\right)^{2}$ sehingga diperoleh $\pi=\left(\frac{16}{9}\right)^{2}=\frac{256}{81}=3,1604$ (Bailey et al., 1997).

Peneliti berlomba-lomba memecahkan rekor untuk memformulasikan cara agar mereka mendapatkan digit terbanyak dari $\pi$. Contohnya pada 16 Oktober 2011 seorang matematikawan bernama Ahigeru Kondo yang berasal dari Jepang berhasil memperoleh digit $\pi$ hingga 10 triliyun (Syam, 2017). Namun yang akan dikaji pada penelitian ini bukan terkait dengan menemukan digit terbanyak dari $\pi$, penelitian ini akan membahas tentang pemahaman mahasiswa Teknik Sipil Universitas Banten Jaya terhadap nilai $\pi$ yang digunakan pada pembahasan materi keliling dan luas lingkaran karena pemahaman yang berbeda terhadap nilai $\pi$ akan menimbulkan selisih yang cukup besar terhadap perhitungan yang dilakukan.

\section{METODOLOGI PENELITIAN}

Penelitian yang dilakukan merupakan penelitian deskriptif kualitatif yang menceritakan fakta dan kondisi mahasiswa Program Studi Teknik Sipil di Universitas Banten Jaya dalam pemahaman mengenai 
nilai $\pi$ pada konsep keliling dan luas lingkaran. Mahasiswa semester III menjadi subjek penelitian karena pada semester III mahasiswa di Program Studi Teknik Sipil wajib menyelesaikan mata kuliah matematika terapan sehingga sebelum memulai mata kuliah tersebut jika dosen ingin membahas materi yang terkait bangun ruang maka konsep-konsep dasar seperti pemahaman terhadap nilai $\pi$ harus mahasiswa kuasai. Kriteria inklusi dalam penelitian ini diantaranya: (1) mahasiswa teknik sipil Universitas Banten Jaya; (2) mengontrak mata kuliah matematika terapan; (3) mahasiswa yang telah mempelajari materi matematika tentang keliling dan luas lingkaran baik di tingkat sekolah menengah maupun sekolah menengah atas. Instrumen penelitian berupa pertanyaan yang terdiri dari 5 buah soal uraian singkat terkait keliling dan luas lingkaran. Soal diberikan kepada mahasiswa melalui google form, karena pada saat ini pembelajaran masih dilakukan secara online sehingga baik pengajaran maupun penelitian yang dilakukan yang berhubungan dengan mahasiswa harus menggunakan aplikasi yang dapat diakses secara online. Setelah hasil diperoleh dan dikumpulkan kemudian peneliti melakukan wawancara terhadap mahasiswa berdasarkan data yang mereka kumpulkan untuk memperoleh informasi yang lebih akurat. Terdapat beberapa equation yang digunakan dalam penelitian ini diantaranya sebagai berikut:

$$
\begin{aligned}
& L=\pi r^{2} \quad \ldots(1) \\
& K=2 \pi r \ldots(2)
\end{aligned}
$$

\section{DATA DAN ANALISA}

Coba amati perhitungan yang dilakukan berikut ini, apabila dilakukan perhitungan luas lingkaran dengan penggunaan jumlah desimal nilai $\pi$ yang berbeda. Pertama kita akan menghitung luas lingkaran dengan $\mathrm{r}=1$ maka akan diperoleh perhitungan sebagai berikut:

Untuk $\pi=3,14$

$L_{1}=\pi r^{2}=3,14 \times 1^{2}=3,14$

Untuk $\pi=3,141$

$L_{2}=\pi r^{2}=3,141 \times 1^{2}=3,141$

Sehingga untuk $L_{1}$ dan $L_{2}$ diperoleh selisih $3,141-3,14=0,001$

Untuk $\pi=3,14$

$L_{1}=\pi r^{2}=3,14 \times 1^{2}=3,14$

Untuk $\pi=3,1415926535$

$L_{2}=\pi r^{2}=3,1415926535 \times 1^{2}=3,1415926535$

Sehingga untuk $L_{1}$ dan $L_{2}$ diperoleh selisih 3,1415926535 - 3,14=0,0015926535

Untuk jari-jari bernilai $\mathrm{r}=1$ maka selisih yang didapatkan masih dalam bentuk desimal namun jika jarijarinya diperbesar maka selisih yang akan dihasilkan juga akan semakin besar, seperti pada contoh berikut ini:

Misal $r=40$ maka luas lingkaran yang akan diperoleh adalah sebagai berikut.

Untuk $\pi=3,14$

$L_{1}=\pi r^{2}=3,14 \times 40^{2}=5024$

Untuk $\pi=3,141$

$L_{2}=\pi r^{2}=3,141 \times 40^{2}=5025,6$

Sehingga untuk $L_{1}$ dan $L_{2}$ diperoleh selisih 5025,6 - 5024 = 1,6

Untuk $\pi=3,14$ 
$L_{1}=\pi r^{2}=3,14 \times 40^{2}=5024$

Untuk $\pi=3,1415926535$

$L_{2}=\pi r^{2}=3,1415926535 \times 40^{2}=5026,5482456$

Sehingga untuk $L_{1}$ dan $L_{2}$ diperoleh selisih 5026,5482456 - $5024=2,5482456$

Ternyata ketika jari-jari mencapai $r=40$, besar selisih eror luas yang diperoleh sudah mencapai satuan. Selanjutnya coba ambil jari-jari yang ukurannya lebih besar lagi. Misal $r=100$ maka luas lingkaran yang akan diperoleh adalah sebagai berikut.

Untuk $\pi=3,14$

$L_{1}=\pi r^{2}=3,14 \times 100^{2}=31400$

Untuk $\pi=3,141$

$L_{2}=\pi r^{2}=3,141 \times 100^{2}=31410$

Sehingga untuk $L_{1}$ dan $L_{2}$ diperoleh selisih $31410-31400=10$

Untuk $\pi=3,14$

$L_{1}=\pi r^{2}=3,14 \times 100^{2}=31400$

Untuk $\pi=3,1415926535$

$L_{2}=\pi r^{2}=3,1415926535 \times 100^{2}=31415,926535$

Sehingga untuk $L_{1}$ dan $L_{2}$ diperoleh selisih $31415,926535-31400=15,926535$

Bagaimana jika jari-jari lingkaran kita perbesar sampai angka ribuan maka perhitungan selisih eror luas lingkaran yang akan didapatkan adalah sebagai berikut:

Misal $\mathrm{r}=1000$

Untuk $\pi=3,14$

$L_{1}=\pi r^{2}=3,14 \times 1000^{2}=3140000$

Untuk $\pi=3,141$

$L_{2}=\pi r^{2}=3,141 \times 1000^{2}=3141000$

Sehingga untuk $L_{1}$ dan $L_{2}$ diperoleh selisih $3141000-3140000=1000$

Untuk $\pi=3,14$

$L_{1}=\pi r^{2}=3,14 \times 1000^{2}=3140000$

Untuk $\pi=3,1415926535$

$L_{2}=\pi r^{2}=3,1415926535 \times 1000^{2}=3141592,6535$

Sehingga untuk $L_{1}$ dan $L_{2}$ diperoleh selisih $3141592,6535-3140000=1592,6535$

Untuk yang terakhir kita akan mencoba menghitung selisih eror yang akan didapatkan jika $r=10000$

Untuk $\pi=3,14$

$L_{1}=\pi r^{2}=3,14 \times 10000^{2}=314000000$

Untuk $\pi=3,141$

$L_{2}=\pi r^{2}=3,141 \times 1000^{2}=314100000$

Sehingga untuk $L_{1}$ dan $L_{2}$ diperoleh selisih $314100000-314000000=100000$

Untuk $\pi=3,14$

$L_{1}=\pi r^{2}=3,14 \times 10000^{2}=314000000$

Untuk $\pi=3,1415926535$

$L_{2}=\pi r^{2}=3,1415926535 \times 1000^{2}=314159265,35$ 
Sehingga untuk $L_{1}$ dan $L_{2}$ diperoleh selisih $\quad 314159265,35-314000000=159265,35$

Berdasarkan percobaan perhitungan di atas maka semakin besar ukuran suatu benda, jika penafsiran nilai $\pi$ tidak tepat maka akan menimbulkan selisih eror yang cukup besar. Seperti yang kita ketahui bahwa dalam Teknik sipil banyak bahan bangunan yang mengadopsi konsep lingkaran di dalam pembuatannya seperti Buis beton yang memiliki kegunaan sebagai saluran air. Buis beton memiliki bentuk seperti tabung tanpa alas dan tutup, untuk menghitung besar debit air yang dapat mengalir pada buis tersebut maka akan menggunakan nilai $\pi$ dalam perhitungannya.

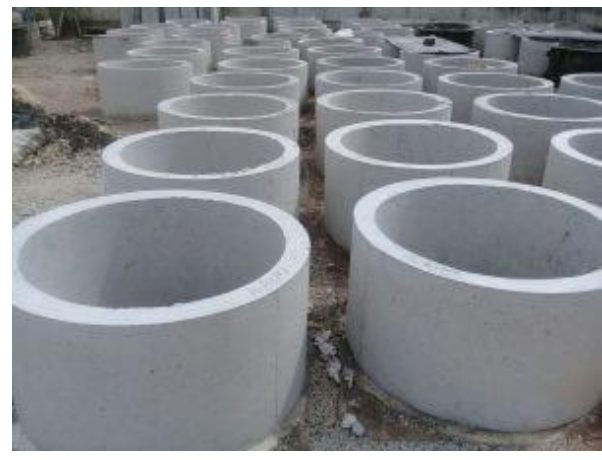

Gambar 2. Buis Beton

(Beton Precast, 2021)

Dikarenakan di dalam penerapan nilai $\pi$ banyak digunakan di dalam teknik sipil maka dosen perlu menganalisis sejauh mana pemahaman mahasiswa terait hal tersebut. Berikut ini merupakan hasil analisis dari beberapa soal yang terkait dengan keliling dan luas lingkaran yang menggunakan konsep nilai $\pi$

Rumus Keliling lingkaran adalah $2 \pi r$. Berapa nilai $\pi$ yang anda ketahui? *

Teks jawaban singkat

Gambar 3. Pertanyaan No 1

Pertanyaan yang ada pada nomor 1 merupakan pertanyaan yang digunakan untuk mengetahui konsep yang tertanam pada benak masing-masing mahasiswa terkait rumus keliling lingkaran dan besaran nilai $\pi$ yang akan digunakan. Apakah ada kesalahan konsep yang dipahami oleh mahasiswa atau mahasiswa sudah memiliki pemahaman yang tepat. Berikut ini merupakan jawaban dari 27 responden yang meruapakan mahasiswa Program Studi Teknik Sipil.

Tabel 1. Rekapitulasi Jawaban Mahasiswa untuk Pertanyaan No 1

\begin{tabular}{cc}
\hline Jawaban Mahasiswa & Jumlah Mahasiswa yang Menjawab \\
\hline 2 & 2 \\
$\frac{22}{7}$ & 1 \\
3,14 & 11 \\
6,28 & 1 \\
$\frac{22}{7}$ atau 3,14 & 9 \\
$\frac{22}{7}$ dan 3,14 & 2 \\
$2 \mathrm{vr}$ & 1 \\
\hline Total & 27 Responden \\
\hline
\end{tabular}


Rumus Keliling lingkaran adalah $2 \pi r$. Berapa nilai $\pi$ yang anda ketahui?

27 tanggapan

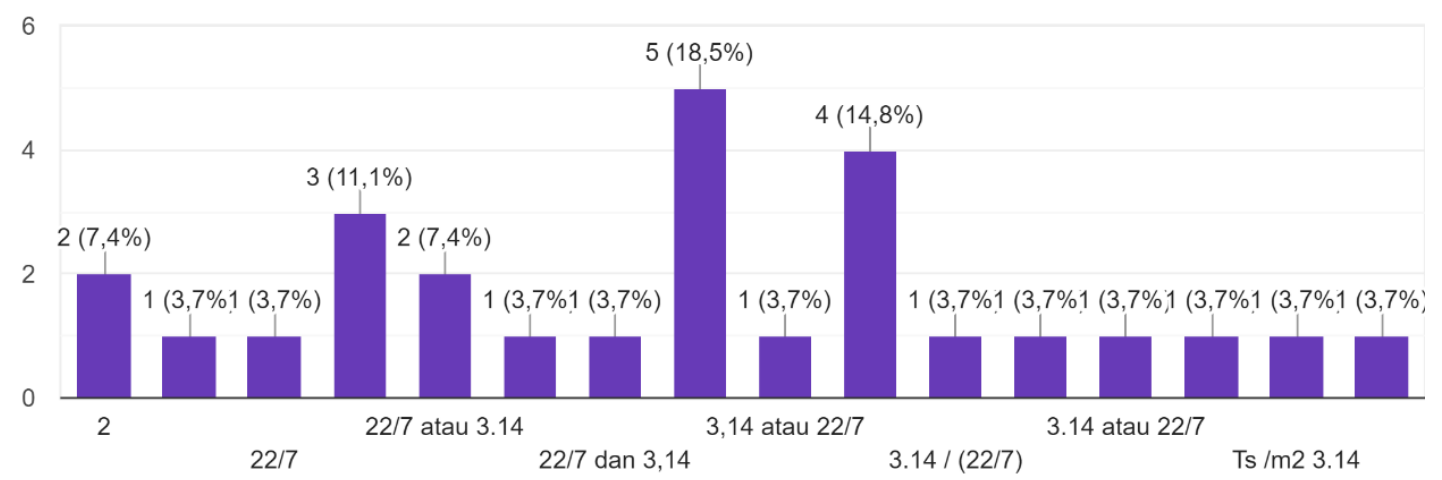

Gambar 4. Jawaban Mahasiswa untuk Pertanyaan No 1

Berdasarkan jawaban yang disampaikan oleh mahasiswa, jika jawaban tersebut dikelompokkan maka akan didapatkan 7,4\% menjawab besar nilai $\pi$ adalah $2 ; 3,7 \%$ menjawab besar nilai $\pi$ adalah $\frac{22}{7} ; 40,8 \%$ menjawab besar nilai $\pi$ adalah 3,14; 3,7\% menjawab besar nilai $\pi$ adalah 6,$28 ; 33,3 \%$ menjawab besar nilai $\pi$ adalah $\frac{22}{7}$ atau 3,14; 7,4\% menjawab besar nilai $\pi$ adalah $\frac{22}{7}$ dan 3,14; serta 3,7\% menjawab besar nilai $\pi$ adalah 2 vr. Jawaban terbanyak yang diperoleh dari mahasiswa menyatakan besar nilai yaitu 3,14 . Apabila banyak mahasiswa yang menjawab nilai $\pi$ adalah 3,14 bagaimana jika mahasiswa diberikan pertanyaan lanjutan yang menggunakan nilai $\pi$ dalam proses pengerjaannya seperti pada pertanyaan no 2 yang menanyakan luas lingkaran jika diketahui jari-jarinya. Pertanyaan tersebut dinyatakan sebagai berikut:

\author{
Jika jari-jari sebuah lingkaran adalah 100 meter maka berapa luas lingkaran tersebut? \\ Teks jawaban singkat
}

Gambar 5. Pertanyaan No 2

Untuk menjawab pertanyaan no 2, mahasiswa memberikan beragam variasi jawaban, diantaranya 3,7\% menjawab $625 \mathrm{~cm}, 3,7 \%$ menjawab $628 \mathrm{~m}, 3,7 \%$ menjawab 628,57, 3,7\% menjawab 10000 (tanpa satuan yang jelas), 3,7\% menjawab 31428,571 m, 22,2\% menjawab 31400 (tanpa satuan yang jelas), $3,7 \%$ menjawab $31400 \mathrm{~cm}^{2}, 22,2 \%$ menjawab $31400 \mathrm{~m}^{2}, 3,7 \%$ menjawab $314000 \mathrm{~m}^{2}, 3,7 \%$ menjawab $31,85,3,7 \%$ menjawab $314 \mathrm{~cm}^{2}, 3,7 \%$ menjawab 31415,93 (tanpa satuan yang jelas), 3,7\% menjawab 35,42 (tanpa satuan yang jelas), 3,7\% menjawab $628 \mathrm{~m}^{2}, 3,7 \%$ menjawab 628,57, serta 3,7\% menjawab $7857 \mathrm{~m}^{2}$. 
Tabel 2. Rekapitulasi Jawaban Mahasiswa untuk Pertanyaan No 2

\begin{tabular}{cc}
\hline Jawaban Mahasiswa & Jumlah Mahasiswa yang Menjawab \\
\hline $625 \mathrm{~cm}$ & 1 \\
$628 \mathrm{~m}$ & 1 \\
628,57 & 1 \\
10000 & 1 \\
$31428,571 \mathrm{~m}$ & 1 \\
31400 & 6 \\
$31400 \mathrm{~cm}^{2}$ & 1 \\
$31400 \mathrm{~m}^{2}$ & 6 \\
$314000 \mathrm{~m}^{2}$ & 1 \\
31,85 & 1 \\
35,42 & 1 \\
$314 \mathrm{~cm}^{2}$ & 1 \\
31415,93 & 1 \\
35,42 & 1 \\
$628 \mathrm{~m}^{2}$ & 1 \\
628,57 & 1 \\
$7857 \mathrm{~m}^{2}$ & 1 \\
Total & $\mathbf{2 7}$ Responden \\
\hline
\end{tabular}

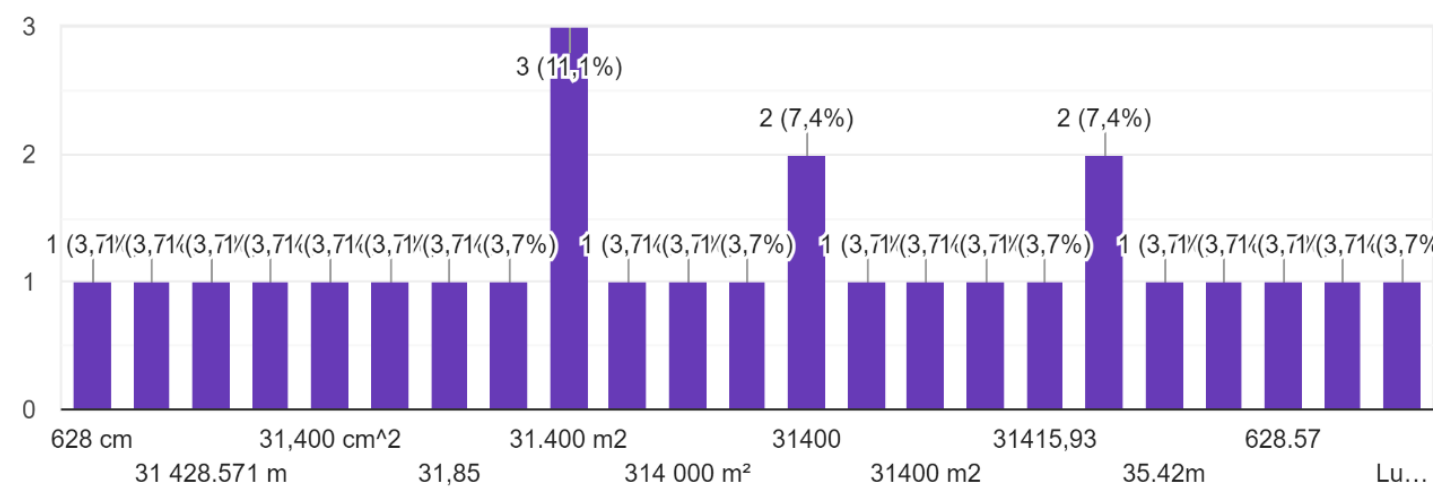

Gambar 6. Jawaban Mahasiswa untuk Pertanyaan No 2

Pertanyaan yang muncul ketika menganalisis hasil tersebut adalah dengan cara apa mahasiswa mendapatkan jawaban tersebut. Berdasarkan hasil wawancara yang dilakukan kepada mahasiswa, cara mereka mendapatkan jawaban tersebut adalah sebagai berikut:

Jawaban 10000

Mahasiswa menggunakan cara $L=s \times s$ yang seharusnya digunakan untuk mencari luas segiempat sehingga luas lingkaran yang diperoleh adalah $L=s \times s=100 \times 100=10000$

Ini merupakan sesuatu pemahaman yang keliru sehingga diperlukan pendampingan dari dosen untuk menjelaskan kekeliruan yang terjadi. 
Jawaban 628

Mahasiswa menggunakan cara $L=2 \pi r$ yang seharusnya digunakan untuk mencari keliling lingkaran sehingga luas lingkaran yang diperoleh adalah $L=2 \pi r=2 \times 3,14 \times 100=628$

Ternyata masih ada mahasiswa yang belum mampu untuk membedakan cara yang digunakan saat mencari keliling lingkaran dan cara yang digunakan saat mencari luas lingkaran.

\section{Jawaban 31400}

Mahasiswa menggunakan cara $L=\pi r^{2}$ yang seharusnya digunakan untuk mencari keliling lingkaran sehingga luas lingkaran yang diperoleh adalah $L=\pi r^{2}=3,14 \times 100 \times 100=31400$

Secara unum, 14 orang mahasiswa menjawab luas lingkaran tersbeut adalah 31400 (dengan satuan yang berbeda beda yaitu $\mathrm{cm}^{2}$ dan $\mathrm{m}^{2}$ atau tanpa satuan yang dicantumkan). Mahasiswa secara langsung menggunakan nilai $\pi=3,14$, mungkin hal ini terjadi karena persepsi yang tertanam pada pemahaman masing-maisng mahasiswa bahwa mereka dapat langsung menggunakan $\pi=3,14$ sebagai suatu pendekatan untuk menyelesaikan permasalahan yang memerlukan nilai $\pi$ pada hasil akhirnya.

Pendekatan nilai $\pi$ yang digunakan selama ini merupakan perbandingan natara keliling lingkaran dan diameter lingkaran. Jika kita memisalkan $K$ sebagai keliling lingkaran dan $d$ sebagai diameter lingkaran maka perbandingan natar keliling dan diameter lingkaran atau yang kita sebut sebagai nilai pendekatan dari $\pi$ adalah sebagai berikut:

$$
\frac{K}{d}=\frac{44}{14}=\frac{22}{7}
$$

Untuk membuat nilai tersebut lebih sederhana dalam penggunaannya, banyak buku paket yang menyimpulkan nilai $\pi=3,14$. Padahal jika kita menggunakan kalkulator, hasil dari $\pi=\frac{22}{7}$ menghasilkan banyak sekali bilangan desimal yang berada di belakang angka 3. Apabila hasil perhitungan tersebut secara langsung dibulatkan menjadi 2 angka desimal maka akan menghasilkan perhitungan yang keliru jika jari-jari yang ditetapkan ukurannya cukup besar. Jika kita mencoba menyelesaikan permasalahan yang ada pada pertanyaan no 2 dengan pendekatan $\pi=\frac{22}{7}$ maka hasil yang akan didapatkan adalah sebagai berikut:

$$
\begin{aligned}
& L=\pi r^{2} \\
& L=\frac{22}{7} \times 100 \times 100 \\
& L=\frac{220000}{7} \\
& L=31428,5714 \mathrm{~m}^{2}
\end{aligned}
$$

Berdasarkan hasil jawaban mahasiswa terdapat 1 orang responden yang menjawab luas lingkaran tersebut adalah $31428,5714 \mathrm{~m}^{2}$, sedangkan 26 responden lainnya menjawab dengan jawaban yang memiliki selisih cukup besar dengan nilai tersebut, selisih yang didapatkan yaitu:

Untuk jawaban $625 \mathrm{~cm}^{2}$

Pertama konversikan nilai $31428,5714 \mathrm{~m}^{2}$ ke dalam $\mathrm{cm}^{2}$ sehingga didapatkan $314285714 \mathrm{~cm}^{2}$

Selisih jawabannya yaitu $314285714-625=314285089 \mathrm{~cm}^{2}$

Untuk jawaban $628 \mathrm{~m}^{2}$

Selisih jawabannya $31428,5714-628=30800,5714 \mathrm{~m}^{2}$ 
Untuk jawaban $10000 \mathrm{~m}^{2}$

Selisih jawabannya $31428,5714-10000=21428,5714 \mathrm{~m}^{2}$

Untuk jawaban $31400 \mathrm{~cm}^{2}$

Pertama konversikan nilai 31428,5714 $\mathrm{m}^{2}$ ke dalam $\mathrm{cm}^{2}$ sehingga didapatkan $314285714 \mathrm{~cm}^{2}$

Selisih jawabannya yaitu $314285714-31400=314254314 \mathrm{~cm}^{2}$

Untuk jawaban $31400 \mathrm{~m}^{2}$

Selisih jawabannya $31428,5714-31400=28,5714 \mathrm{~m}^{2}$

Coba perhatikan jika kita langsung menggunakan nilai $\pi=3,14$, akan menghasilkan selisih luas yang cukup besar untuk pertanyaan tersebut. Selisih yang dihasilkan mencapai $28,5714 \mathrm{~m}^{2}$. Coba bayangkan jika dalam merencanakan suatu pembangunan namun terjadi kesalahan perhitungan maka apa yang akan terjadi? Jika membangun jalan maka jalan yang dihasilkan akan cepat rusak, jika membangun suatu jembatan maka jembatan tersebut akan cepat roboh dan tidak mampu menampung beban yang besar, dan jika membangun rumah maka rumah yang dihasilkan akan mudah retak atau tidak tahan akan guncangan. Bagaimana jika mahasiswa diberikan pertanyaan lanjutan yang menggunakan nilai $\pi$ dalam proses menemukan suatu keliling lingkaran, seperti pada pertanyaan no 3 berikut ini:

Jika jari-jari sebuah lingkaran adalah 350 meter maka berapa keliling lingkaran tersebut? *

Teks jawaban singkat

\section{Gambar 7. Pertanyaan No 3}

Variasi jawaban yang diberikan oleh mahasiswa untuk menjawab pertanyaan no 3 diantaranya, 3,7\% menjawab $1100 \mathrm{~cm}, 3,7 \%$ menjawab 111,46 (tanpa satuan yang jelas), 3,7\% menjawab 122500 (tanpa satuan yang jelas, 14,8\% menjawab 2200 (tanpa satuan yang jelas), 14,8\% menjawab $2200 \mathrm{~m}, 18,5 \%$ menjawab 2198 (tanpa satuan yang jelas), 7,4\% menjawab $2198 \mathrm{~cm}, 14,8 \%$ menjawab $2198 \mathrm{~m}, 3,7 \%$ menjawab 2199,11 (tanpa satuan yang jelas), 3,7\% menjawab 384,1 m, 3,7\% menjawab 549,5 (tanpa satuan yang jelas), 3,7\% menjawab 66,25 (tanpa satuan yang jelas serta 3,7\% menjawab $770000 \mathrm{~m}^{2}$. Jawaban yang mahasiswa berikan dapat dilihat pada Tabel 3 dan Gambar 8.

Tabel 3. Rekapitulasi Jawaban Mahasiswa untuk Pertanyaan No 3

\begin{tabular}{cc}
\hline Jawaban Mahasiswa & Jumlah Mahasiswa yang Menjawab \\
\hline $1100 \mathrm{~cm}$ & 1 \\
111,46 & 1 \\
122500 & 1 \\
2200 & 4 \\
$2200 \mathrm{~m}$ & 4 \\
2198 & 5 \\
$2198 \mathrm{~cm}$ & 2 \\
$2198 \mathrm{~m}$ & 4 \\
2199,11 & 1 \\
384,1 & 1 \\
549,5 & 1 \\
66,25 & 1 \\
$770000 \mathrm{~m}^{2}$ & 1 \\
\hline Total & $\mathbf{2 7}$ Responden \\
\hline
\end{tabular}




\begin{abstract}
Jika jari-jari sebuah lingkaran adalah 350 meter maka berapa keliling lingkaran tersebut? 27 tanggapan
\end{abstract}

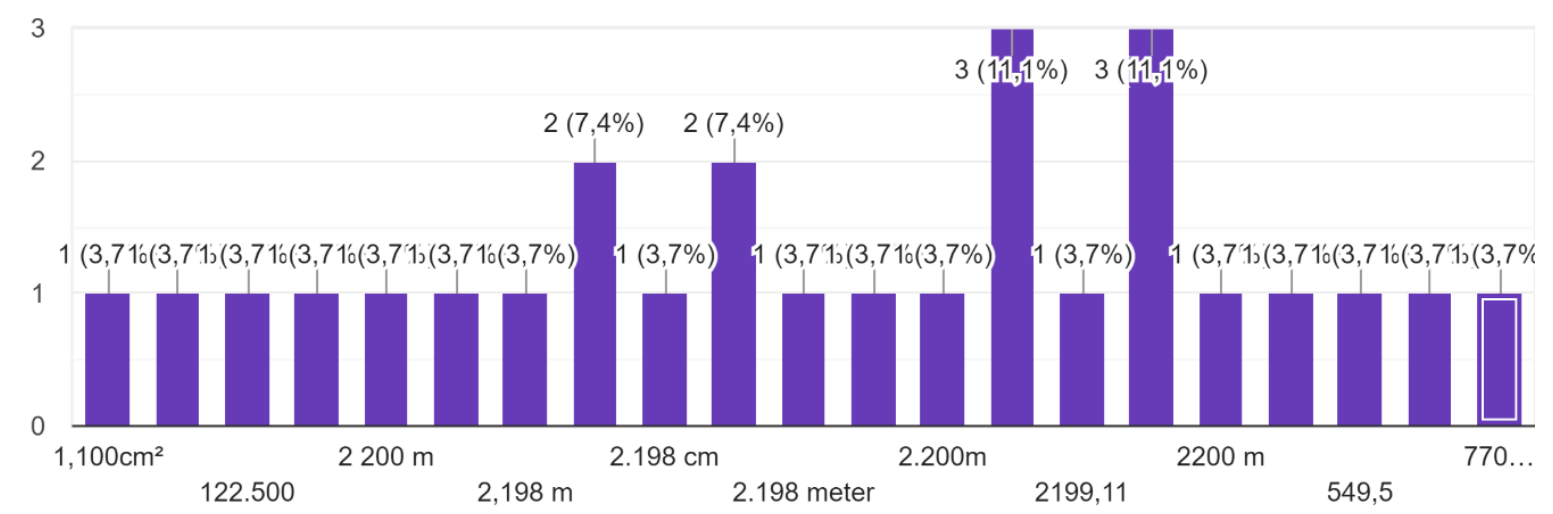

Gambar 8. Jawaban Mahasiswa untuk Pertanyaan No 3

Berdasarkan berbagai variasi jawaban yang muncul selanjutnya silakukan wawancara lanjutan untuk mengkonfirmasi Langkah yang mahasiswa lakukan untuk menghasilkan jawaban-jawaban tersebut. Hasil wawancara yang diperoleh adalah sebagai berikut:

Jawaban $1100 \mathrm{~cm}^{2}$

Mahasiswa menggunakan cara $K=3,14285 \times r$ sehingga diperoleh hasil $K=3,14285 \times 350=$ 1099,9975 kemudian ia membulatkan hasilnya menjadi 1100. Ini merupakan kekeliruan konsep keliling lingkaran sehingga mahasiswa menggunakan cara yang tidak tepat untuk menyelesaikan permasalahan yang diberikan.

\title{
Jawaban 122500
}

Mahasiswa menggunakan cara $K=r \times r$. Saat diwawancarai mahasiswa masih kebingungan untuk membedakan konsep luas dan keliling, bahkan jika diamati cara yang ia gunakan lebih mirip dengan cara untuk menemukan luas persegi yang mengkalikan sisi-sisinya. Ia bahwkan belum mampu membedakan sis dan jari-jari. Sehingga yang ia lakukan hanya mengkalikan jari-jarinya saja,

$K=r \times r=350 \times 350=122500$.

\section{Jawaban $770000 \mathrm{~m}^{2}$}

Mahasiswa menggunakan cara $K=22 \times r \times 100=22 \times 350 \times 100=770000 \mathrm{~m}^{2}$.

Saat diberikan pertanyaan lanjutan mengenai cara tersebut, ia menyatakan bahwa 22 merupakan nilai $\pi$ sedangkan 100 merupakan angka yang harus digunakan ketika ingin mencari suatu keliling lingkaran.

Jawaban $2198 \mathrm{~m}$

Mahasiswa menggunakan cara $K=2 \times \pi \times r$ dengan besar nilai $\pi=3,14$ sehingga diperoleh hasil

$K=2 \times \pi \times r=2 \times 3,14 \times 350=2198 m$ 
Jawaban $2200 \mathrm{~m}$

Mahasiswa menggunakan cara $K=2 \times \pi \times r$ dengan besar nilai $\pi=\frac{22}{7}$ sehingga diperoleh hasil

$K=2 \times \pi \times r=2 \times \frac{22}{7} \times 350=2200 m$

Jawaban terbanyak (11 orang) yang diberikan oleh mahasiswa menyebutkan bahwa keliling lingkaran tersebut adalah 2198. Bagaimana kika kita mencoba menyelesaikan permasalahan yang ada pada pertanyaan no 3 dengan pendekatan $\pi=\frac{22}{7}$ yang merupakan perbandingan antara keliling dan diameter lingkaran maka hasil yang akan didapatkan adalah sebagai berikut:

$$
\begin{aligned}
K & =2 \pi r \\
K & =2 \times \frac{22}{7} \times 350 \\
K & =2200 \mathrm{~m}
\end{aligned}
$$

Jawaban di atas memiliki selisih 2 meter dengan jawaban yang paling banyak dijawab oleh mahasiswa. Selisih pengukuran yang cukup besar dan akan menjadi fatal jika konsep perhitungan yang salah digunakan di dalam penerapan ilmu teknik sipil karena akan mengakibatkan kesalahan perhitungan dalam membangun sebuah bangunan. Untuk mengatasi hal tersebut dibutuhkan persamaan persepsi terhadap nilai $\pi$.

Menurut Sari (2017) terdapat kesalahan alur belajar yang mahasiswa terima saat ia duduk di bangku sekolah dasar maupun menengah, penjelasan mengenai materi lingkaran dilakukan dengan memberikan rumus keliling dan luas lingkaran, mengerjakan contoh soal dan diakhiri dengan latihan yang mirip bahkan sama persis hanya berbeda angka dengan contoh yang diberikan oleh guru. Guru seringkali lupa untuk mengarahkan pembelajaran dengan cara siswa menemukan rumus keliling dan luas lingkaran sendiri. Sebelum mengajak siswa menemukan rumus sendiri, tentu siswa harus mengetahui terlebih dahulu tentang konsep nilai $\pi$. Penemuan nilai $\pi$ tersebut dapat dilakukan dengan berbagai cara dan percobaan dengan menggunakan barang-barang yang dapat kita temukan di sekitar seperti berikut ini:

1. Dosen menampilkan ilustrasi berupa gambar yang disajikan dalam geogebra untuk menemukan perbandingan antara keliling dan diameter lingkaran

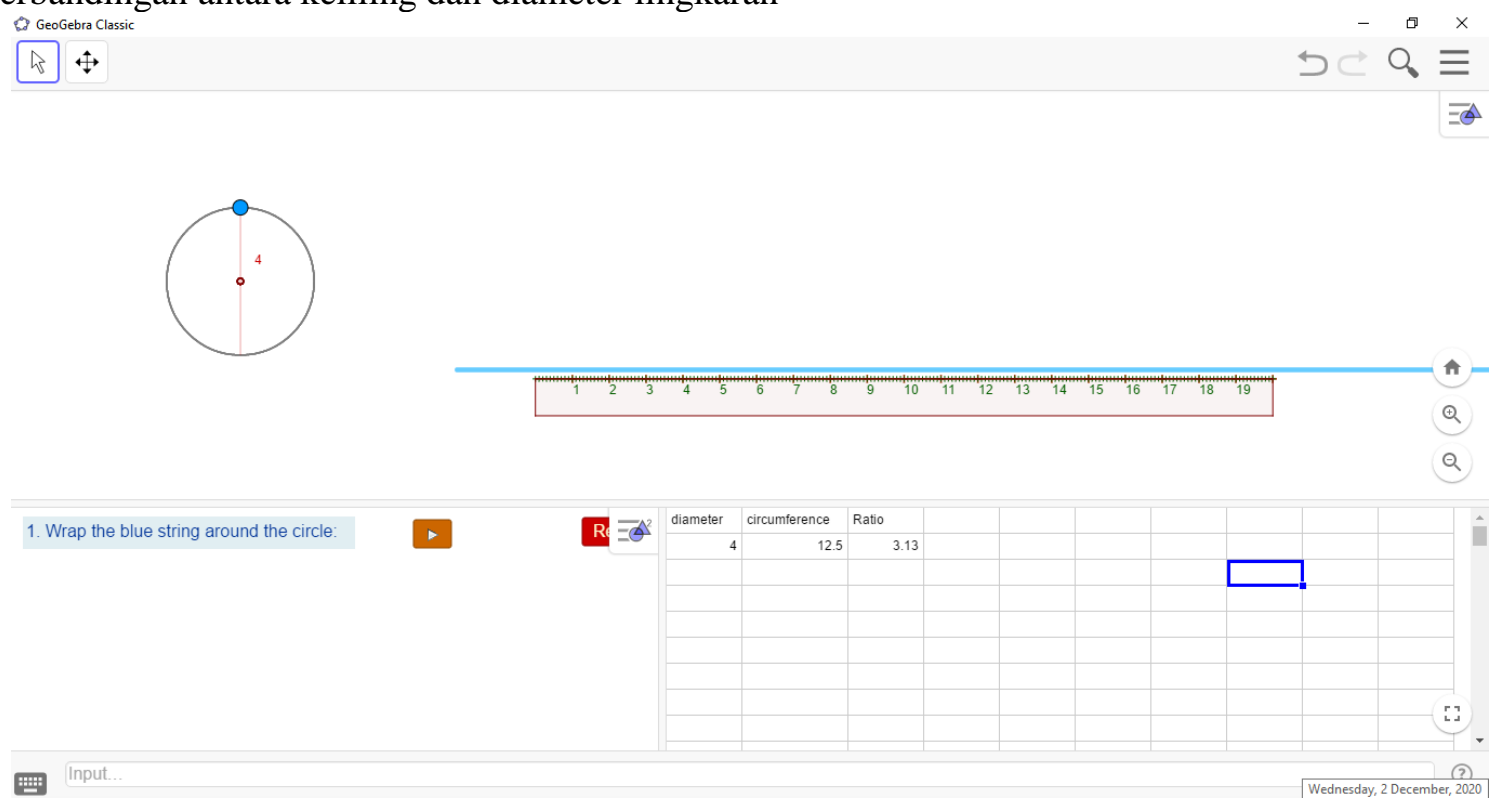

Gambar 9. Ilustrasi yang Ditampilkan pada Geogebra 
2. Dosen menampilkan ilustrasi melilitkan tali pada lingkaran yang telah digambarkan

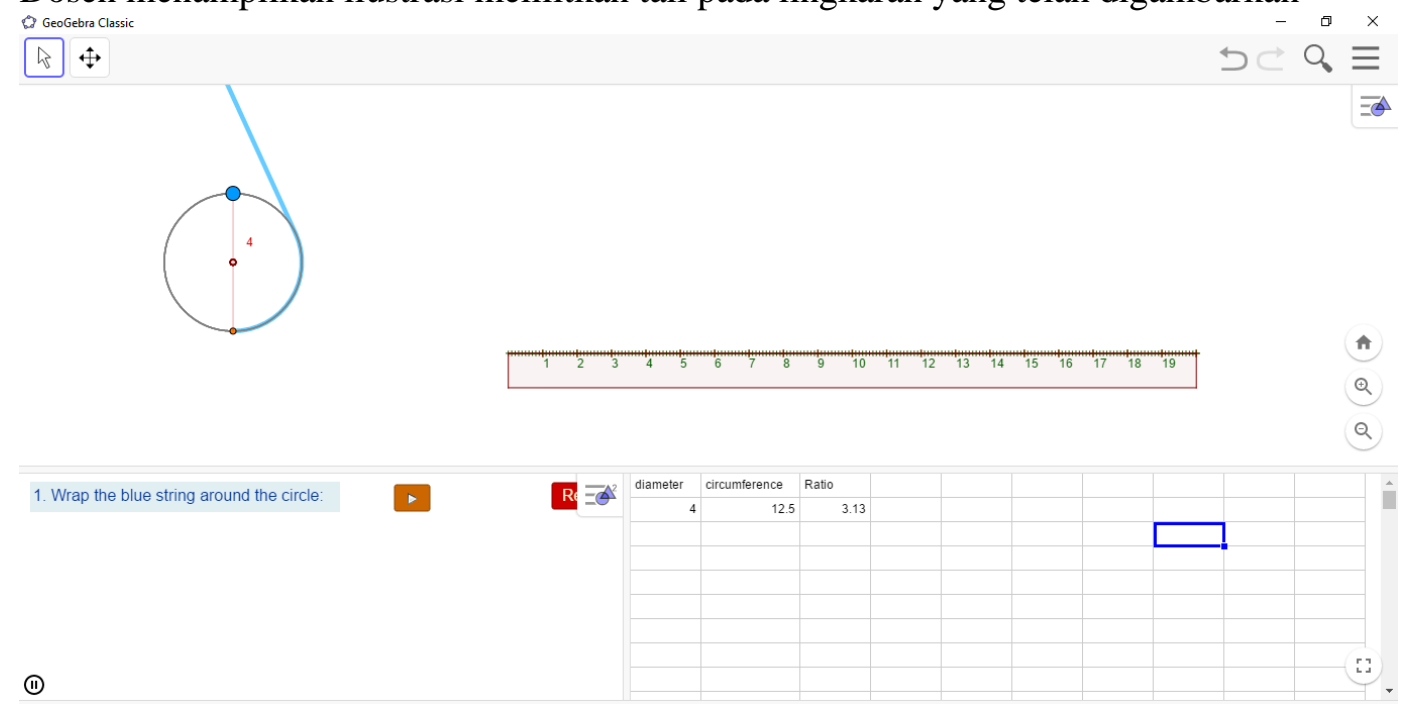

Gambar 10. Ilustrasi Melilitkan Tali pada Keliling Lingkaran

3. Dosen menjelaskan bahwa tali harus ditandai pada posisi tali yang tepat melilit satu buah keliling lingkaran kemudian buka lilitan tersebut dan letakkan di atas mistar.

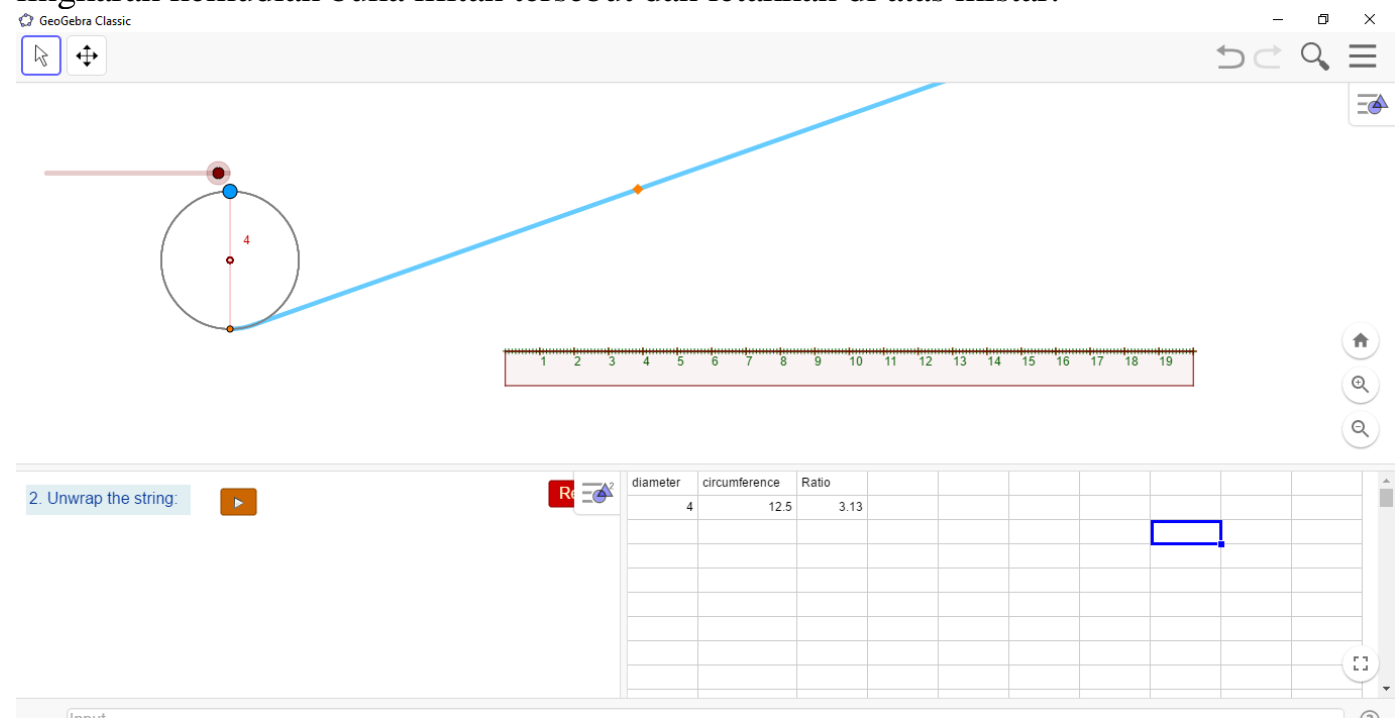

Gambar 11. Membuka Lilitan Benang Setelah Ditandai

4. Dosen menjelaskan bahwa siswa harus mengukur diameter dan keliling lingkaran menggunakan mistar, kemudian data yang diperoleh dituliskan pada buku catatan masing-masing mahasiswa. 


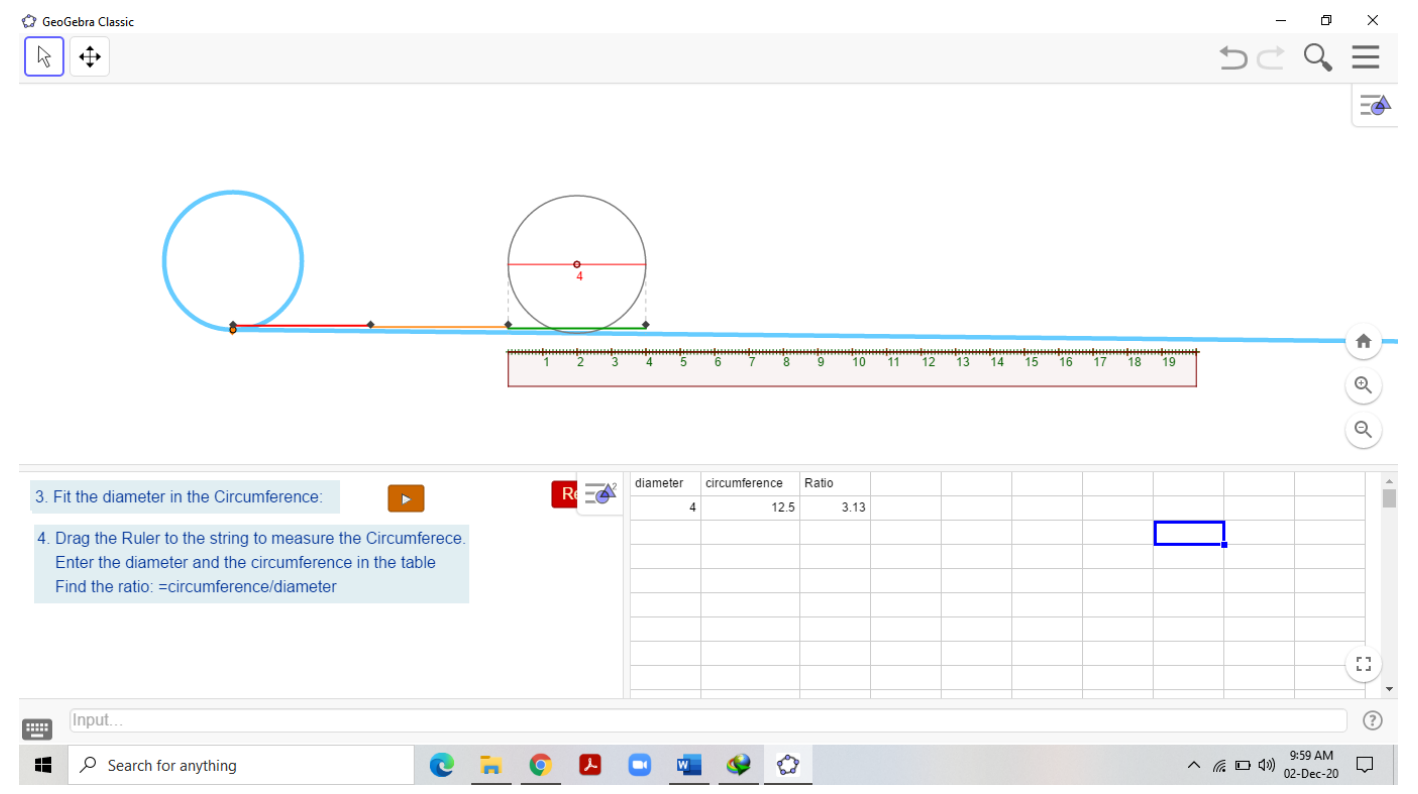

Gambar 12. Ilustrasi Mengukur Panjang Keliling dan Diameter Lingkaran

5. Mahasiswa melakukan perbandingan keliling lingkaran dengan diameter lingkaran untuk menjelaskan konsep nilai $\pi$.Perlu untuk diingatkan bahwa jika mahasiswa melakukan percobaan melilitkan benang pada suatu benda berbentuk lingkaran dan kemudian diminta untuk mengukur diameter serta panjang benang yang terpakai untuk dililitkan pada kelilingnya maka dosen harus memberitahu kepada mahasiswa untuk melakukannya secara teliti dan hati-hati karena kesalahan pengukuran akan berpengaruh kepada hasil pencatatan panjang diameter lingkaran dan keliling lingkaran yang akan mempengaruhi perbandingan diantara pengukuran tersebut.

Walupun pembahasan ini seharusnya sudah dikuasai oleh mahasiswa di bangku sekolah menengah bahkan bangku sekolah dasar, namun tidak ada salahnya jika sebelum menjelaskan tentang penerapannya dalam bidang teknik sipil, materi ini dibahas kembali.

\section{KESIMPULAN}

Berdasarkan analisis data yang dilakukan dapat disimpulkan bahwa banyak mahasiswa yang memiliki pemahaman yang belum tepat terhadap nilai $\boldsymbol{\pi}$ yang digunakan dalam menentukan keliling dan luas lingkaran.Hal ini dikarenakan pemahaman yang dimiliki mahasiswa semenjak di tingkat sekolah dasar kurang tepat, sehingga ingatan itulah yang mereka gunakan untuk menyelesaikan permasalahan yang diberikan. Untuk pertanyaan nomor 2 hanya 1 orang dari 27 orang responden yang mampu menjawab dengan benar dan tepat dan untuk pertanyaan nomor 3 hanya 4 orang dari 27 orang responden yang dapat menjawab dengan benar dan tepat. Rendahnya pemahaman tersebut harus dijadikan sebagai catatan untuk dosen yang mengajar mata kuliah matematika terapan bahwa sebelum menjelaskan penerapan nilai $\boldsymbol{\pi}$, maka sebaiknya diberikan penjelasan kembali tentang dari mana nilai $\boldsymbol{\pi}$ diperoleh, besar nilai $\boldsymbol{\pi}$, serta contoh penggunaan nilai $\boldsymbol{\pi}$.

\section{DAFTAR PUSTAKA}

Bailey, D. H., Borwein, J. M., Borwein, P. B., \& Plouffe, S. M. (1997). The quest for Pi. Mathematical Intelligencer, 19(1), 50-57. https://doi.org/10.1007/bf03024340

Beton Precast. (2021). Beton Precast. Macam - Macam Jenis Beton Pracetak Di Indonesia. https://betonprecast.com/jenis-beton-pracetak/ 
Borwein, J. M. (2011). The Life of Pi: From Archimedes to Eniac and Beyond. 1-30. http://thecarma.net/jon/pi-2012.pdf

Clemens, S. R., O’Daffer, P. G., \& Cooney, T. J. (1984). Geometry: with applications and problem solving. Addison-Wesley Publishing Company, Inc.

Lembaga Alkitab. (1994). Alkitab Terjemahan Baru.

Likuang, T. (2019). 6. Likuang.pdf. Daftar Huruf Di Alfabet Yunani (Greek Alphabet). https://www.tomatalikuang.com/2019/11/daftar-huruf-di-alfabet-yunani.html

Posamentier, Alfred \& Lehmann, I. (2004). $\pi$ : Biography of the World's Most Mysterious Number. Prometheus Books Publisher. https://doi.org/10.5860/choice.42-2859

Sari, N. (2017). Menemukan Nilai Phi dan Rumus Keliling Lingkaran Menggunakan Pendekatan PMRI di Kelas VI. Jurnal Dosen Universitas PGRI Palembang, 20, 1139-1148.

Syam, M. A. (2017). Penentuan Kriteria Demarkatifuntuk Nilai $\pi$ dalam Penerapannya Secara Praktis. Universitas Islam Negeri Alauddin Makassar. 